\title{
Ung gutt med feber, sår hals, såre lepper og bulløst utslett
}

\author{
En gutt i tenårene ble innlagt i en hudavdeling med utslett, feber \\ og nedsatt allmenntilstand. Han hadde sår hals, hovne og sprukne \\ lepper, erosive forandringer i munnslimhinnen, røde øyne, smertefullt \\ utslett genitalt og kløende utslett på kroppen. Det ble et komplisert \\ sykdomsforløp.
}

En tidligere stort sett frisk gutt i tenårene ble innlagt som tiltrengende øyeblikkelig hjelp i en hudavdeling. De siste to årene hadde han hatt 4-5 episoder med små sår i munnslimhinnen $i$ etterkant av forkjølelse. Uken før innleggelsen hadde han fått gradvis økende sårhet i halsen samt hevelse, sprekker og sår på lepper og munnslimhinne, etter hvert også røde øyne, smertefullt utslett på penis og redusert allmenntilstand. Natten før innleggelsen hadde han fått kløende utslett på overkropp og armer.

Ved innkomst var pasienten $i$ betydelig redusert allmenntilstand, takykard og med en kroppstemperatur rundt på $40^{\circ} \mathrm{C}$. Ved undersøkelse ble det påvist uttalt keilitt (fig 1), stomatitt og bilateral konjuktivitt. På preputiet og glans penis var det enkelte slappe bullae. På truncus og overekstremiteter hadde han spredte erytematøse papler, de fleste ekskorierte, men ingen vesikler, pustler eller petekkier. Submandibulært hadde han lett forstørrede lymfeknuter. Ved auskultasjon var det krepitasjoner over nedre tredel av venstre lunge.

Ananmese og kliniske funn ga grunnlag for å mistenke en av to mulige diagnoser: Beçhets sykdom eller erythema multiforme. Beçhets sykdom kjennetegnes av residiverende små ulcerasjoner i munnslimhinne og/ eller genitalslimhinne, artritt, øyeaffeksjon og kutane, gastrointestinale og nevrologiske manifestasjoner (1). Utslettet kan likne på utslett ved andre sykdommer, blant annet erythema nodosum, pyoderma gangrenosum og Sweets syndrom. Erythema multiforme kjennetegnes av et småflekkete, karakteristisk utslett, lokalisert særlig distalt på ekstremiteter, og slimhinneaffeksjon (2). Erythema multiforme kan utløses av ulike typer infeksjoner, bl.a. herpes labialis og pneumoni (3). I dette tilfellet forelå det klinisk mistanke om pneumoni.

Røntgen thorax viste et pneumonisk suspekt infiltrat på venstre side og en fortetning retrosternalt. Pasienten hadde økt antall leukocytter $\left(20,1 \cdot 10^{\%} /\right.$; referanseverdi 3,5-11,0 - 109) og forhøyet CRP-nivå $(118 \mathrm{mg} / \mathrm{l}$; refe- ranseverdi < $5 \mathrm{mg} / \mathrm{l}$ ). Pasienten ble satt på intravenøs penicillin-og væskebehandling da han ikke var i stand til å drikke.

Natten etter innleggelsen ble utslettet på truncus og overekstremitetene mer utbredt, mer uttalt og endret karakter til multiple, velavgensede, erytematøse infiltrerte lesjoner, enkelte med vesikler, bullae, kruster og erosjoner sentralt. Flere lesjoner hadde et kokardepreg (ringstruktur) typisk for erythema multiforme (fig 2). Pasienten var lyssky og hadde smerter $i$ øynene. Antall leukocytter falt til $9,8 \cdot 10^{\%} / l$.

Diagnosen erythema multiforme ble nå fastslått på klinisk grunnlag. Ved denne tilstanden finnes det karakteristiske lesjoner, oftest distalt på armene, gjerne på fingrene, med et annulært preg, med perifer erytematøs ring og vesikkel- eller bulladanning i sentrum (2). Det morfologiske bildet kan imidlertid variere (multiformt), og hos vår pasient var lesjonene preget av bulladanning perifert i lesjonene. Hos den enkelte pasient har likevel de fleste lesjonene ofte et ensartet (monoformt) preg.

Disse lesjonene kalles ofte irislesjoner, blinklesjoner (engelsk: target lesions) eller kokarder - etter merket de franske revolusjonære hadde på luene sine (senere også brukt på norske student- og russeluer). Slimhinner kan være involvert, spesielt øye- og munnslimhinner. Med og uten slimhinneaffeksjon kalles sykdommen henholdsvis erythema multiforme major og erythema multiforme minor.

Erythema multiforme regnes som en immunologisk mediert hypersensitivitetssykdom. I uttalte tilfeller gir man oftest systemisk immunsuppressiv behandling i form av prednisolon, men i enkelte tilfeller kan det være aktuelt å vurdere andre immunsuppressive legemidler $(4,5)$. Sekundærinfeksjon må forebygges, eventuelt behandles.

På grunn av økende utslett fikk pasienten prednisolon $30 \mathrm{mg} \times 2$ per os, noe som tilsvarer $1 \mathrm{mg} / \mathrm{kg}$ kroppsvekt/døgn. I tillegg fikk han lokalbehandling med desinfiserende kaliumpermanganatomslag og dibrompropamidinkrem som forebygging. Han fikk gruppe

\author{
Syed Mohammad Husain Rizvi \\ mohammad.rizvi@ous-hf.no \\ Mari Skylstad Kvernebo \\ Nils-Jørgen Mørk \\ Seksjon for hudsykdommer \\ Oslo universitetssykehus, Rikshospitalet \\ Petter Gjersvik \\ Institutt for klinisk medisin \\ Universitetet i Oslo
}


II og III-steroidkrem på utslett, lidokaingel genitalt og lidokain viskøs gel i munnhulen.

Erythema multiforme utløses ofte av herpes simplex. Stomatitt hos slike pasienter kan både være ledd i en tilgrunnliggende herpes labialis eller ledd i erythema multiforme. Påvisning av herpes simplex-virus ved bruk av PCR-teknikk tar tid, først og fremst av logistiske grunner. Det var derfor ikke mulig å utelukke et pågående utbrudd av herpes simplex labialis.

På mistanke om pågående herpes labialis ble pasienten satt på intravenøs behandling med aciklovir. Penicillinbehandlingen ble videreført.

Erythema multiforme er primært en klinisk diagnose. I prebulløs fase kan tilstanden forveksles med urticaria. Urticaria kjennetegnes ved et flyktig, kløende utslett med vabler grunnet dermalt ødem (2). Biopsi kan være til hjelp for å utelukke andre diagnoser, særlig andre bulløse dermatoser, for eksempel bulløst pemfigoid, pemfigussykdommer og dermatitis herpetiformis.

Biopsi fra ferske lesjoner av erythema multiforme viser T-celleinfiltrat i dermis, hovedsakelig av CD4-positive celler, noe som er forenlig med en forsinket hypersensitivitetsreaksjon (type IV-reaksjon) (3).

Ved erythema multiforme major kan man i tillegg observere CD8-positive T-celler (6). Nekrotiske keratinocytter nær svettekanaler er rapportert å være assosiert med legemiddelutløst erythema multiforme (7). De histologiske forandringene er karakteristiske, men ikke patognomoniske.

Direkte immunfluorescens er rapportert å være positiv i over $80 \%$ av tilfellene med nedslag av IgM og C3 (8). Dette kan dermed skille tilstanden fra dermatitis herpetiformis, der man ser IgA-nedslag i dermale papillae (9), og fra pemphigus vulgaris, der man finner karakteristiske IgG-avleiringer i epidermis (10). Ved bulløst pemfigoid ses nedslag langs basalmembranen (11).

Biopsi fra pasientens utslett viste avløsning av epidermis med konfluerende keratinocyttnekroser i de basale deler. I superfisielle del av dermis var det lett inflammasjon med en del granulocytter i kar. Immunfluorescens viste granulære C3-nedslag langs basalmembranen $i$ epidermis. Funnene ga ingen mistanke om andre bulløse sykdommer.
Histologiske funn og immunfluorescensfunn styrket mistanken om erythema multiforme. Denne sykdommen kan utløses av mange typer infeksjoner som pasienten må utredes for.

Ved innkomst viste røntgen thorax en diffus velavgrenset fortetning bak nedre del av sternum. Det ble derfor tatt CT thorax, der man ikke gjenfant fortetningen, men som viste pneumoniske infiltrater i begge lungene.

Som ledd $i$ en infeksjonsmedisinsk utredning ble det rekvirert blodkultur, pneumokokkantigen i urin, ekspektoratprøve, serologiske prøver på hiv, hepatitt B-virus, hepatitt C-virus, syfilis og borrelia samt prøver for påvisning av herpes simplex-virus og varicella zoster-virus ved PCR. For å utelukke immunsvikt ble det gjort serumelektroforese, kvantitering av immunglobuliner og $T$ - og B-celler med subklasseanalyser.

Ved mikrobiologisk undersøkelse av dyp neseprøve ble det påvist Mycoplasma pneumonia. Man konkluderte med at pasientens erythema multiforme var utløst av Mycoplasma pneumonia. Pasienten ble derfor satt på azitromax $500 \mathrm{mg} \times 1$, samtidig som acyklovir og penicillin ble seponert. På dette tidspunktet var pasienten blitt afebril.

Mycoplasma pneumonia er et vanlig respiratorisk patogen som kan føre til varierende grad av sykdom, alt fra mild infeksjon i øvre luftveier til alvorlig pneumoni. M. pneumoniae gir ofte mild infeksjon og kan være selvbegrensende. Behandling med makrolider eller tetrasyklin synes å være mer effektivt enn penicillinbehandling (12).

Vår pasient fikk penicillinbehandling i ett døgn og ble bedre. Det er uvisst om penicillinet faktisk hadde effekt på den aktuelle mykoplasmainfeksjonen, om bedringen var spontan eller om pasienten hadde en annen bakteriell infeksjon i tillegg.

Pasienten fikk i løpet av oppholdet flere tilsyn av øyelege, som ikke fant tegn til sammenvoksing av slimhinnene i øyet, såkalt symblefaron, som er en fryktet komplikasjon ved erythema multiforme med øyeaffeksjon. Ørenese-hals-lege fant ingen patologiske funn utover pasientens uttalte stomatitt. Blodutstryk vurdert av hematolog viste kun reaktiv prosess.

Pasienten fikk under oppholdet økende hoste og anga stikkende brystsmerter, spesielt ved dyp inspirasjon. Det ble derfor tatt $E K G$, som var normalt. Nytt røntgen thorax

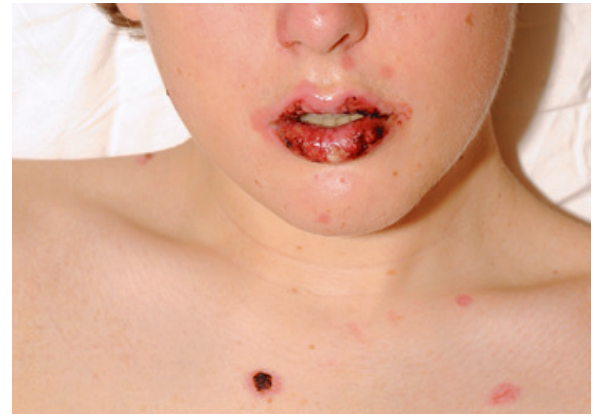

Figur 1 Ved innkomst hadde pasienten uttalt keilitt med erosjoner og kruster. Det er gitt tillatelse til bruk av bildene

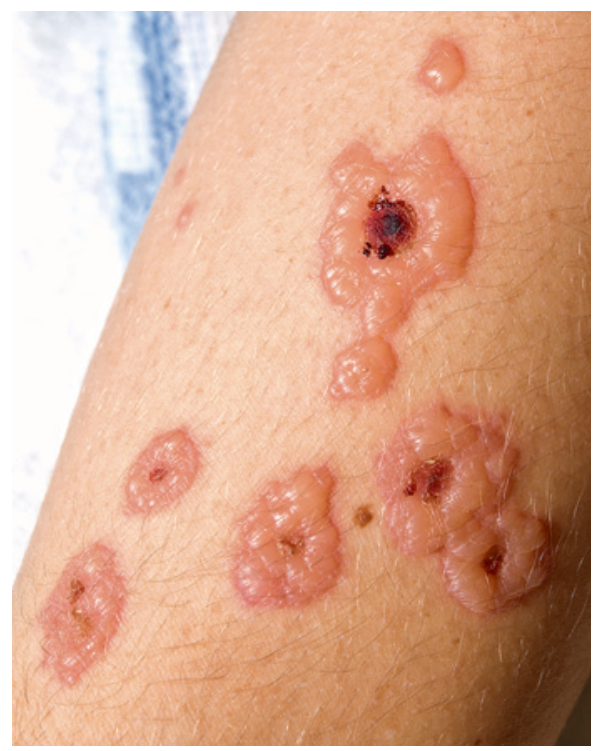

Figur 2 Det første døgnet etter innleggelsen endret utslettet karakter til multiple bulløse kokardelesjoner av varierende størrelse

viste subkutant emfysem på halsen og over høyre skulderparti samt oppklarningslinjer rundt hjertekonturen. Funnene passet best med pneumomediastinum. Lungelege ble involvert, men behandling ble ansett som unødvendig. Røntgenkontroll senere $i$ forløpet viste tilbakegang av forandringene.

Radiologiske tegn på pneumomediastinum fremkommer ved at normale anatomiske strukturer utheves av luft som forlater mediastinum. Pneumomediastinum kan være vanskelig å skille fra pneumothorax og pneumoperikard. CT-undersøkelse kan være til hjelp dersom røntgen thorax ikke gir sikker diagnose (13). Pneumomediastinum kan ha mange årsaker. Hos vår pasient antok vi 


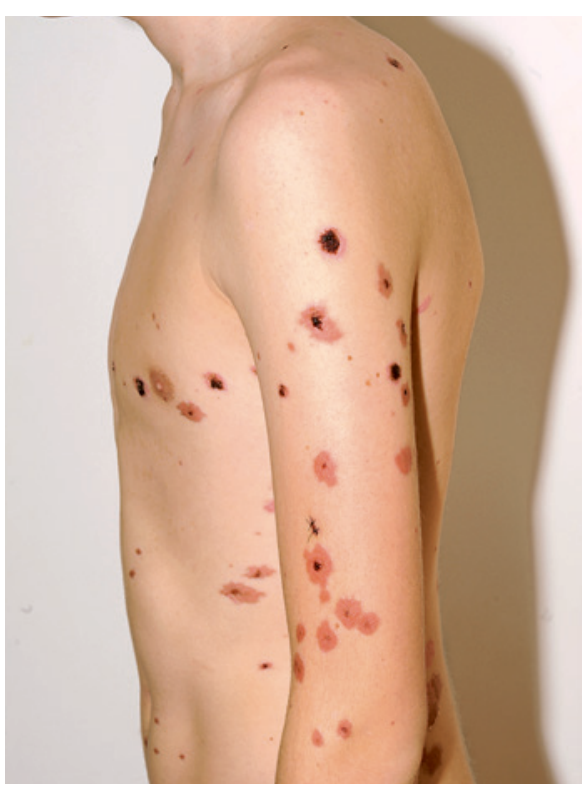

Figur 3 Under oppholdet gikk det bulløse utslettet på ekstremiteter og truncus gradvis tilbake

at årsaken enten var alveolær ruptur eller tette bronkioler.

Utslettet gikk gradvis tilbake (fig 3), og pasienten ble utskrevet i rimelig god form etter 12 dager - med en gradvis nedtrappingsplan på peroral prednisolon samt uendret lokalbehandling. Han var deretter til kontroll hos urolog, som ikke fant tegn til genitale synekier. Ved poliklinisk kontroll ved sykehuset en måned etter utskrivning var pasienten $i$ god allmenntilstand, og utslettet var vesentlig mindre uttalt. Han er senere fulgt opp av fastlegen.

\section{Diskusjon}

Erythema multiforme er en akutt, ofte selvbegrensende tilstand med hudaffeksjon og iblant slimhinneaffeksjon. I milde tilfeller vil man oftest avstå fra behandling. I mer uttalte tilfeller bør pasienten innlegges $i$ sykehus for observasjon og behandling, som regel i hudavdeling eller øre-nese-halsavdeling. Ved progredierende forløp vil man gi immunsuppressiv behandling, spesielt prednisolon. Individer i alle aldre kan rammes, men erythema multiforme ses oftest hos unge voksne i alderen 20-40 år. Tilstanden er noe vanligere hos menn enn hos kvinner og ses hos alle raser. Årlig insidens er anslått til under $1 \%$, men gode epidemiologiske studier mangler $(2,14)$.

Erythema multiforme oppfattes som en immunologisk mediert hypersensitivitetsreaksjon (type IV-reaksjon) med et cytotoksisk immunologisk angrep på keratinocytter (4). Herpes simplex-virus er den vanligste utløsende årsak, mens bakterien Mycoplasma pneumonia regnes som den nest vanligste (2).

Vår pasient hadde erythema multiforme major med både hud- og slimhinneaffeksjon. Han var $\mathrm{i}$ dårlig allmenntilstand med affeksjon av mange organer. Han hadde symptomer og funn fra både hud, munnhule, øyne, genitalia og thorax, i tillegg til temperaturstigning og patologiske funn i blodet. Det komplekse sykdomsbildet gjorde det nødvendig å samarbeide med leger innen flere spesialiteter, bl.a. infeksjonsmedisin, øre-nese-hals-sykdommer, øyesykdommer, lungesykdommer, radiologi og patologi. Denne sykehistorien er et eksempel på at dermatologi som klinisk spesialitet er nær knyttet til andre kliniske og parakliniske spesialiteter.

Pasienten og pasientens pårørende har gitt samtykke til at artikkelen og bildene blir publisert.

Vi takker leger og annet helsepersonell som var med i diagnostikk og behandling av pasienten, spesielt Pål Aukrust.

\section{Syed Mohammad Husain Rizvi (f. 1983)}

er lege under spesialisering ved Seksjon for hudsykdommer, Oslo universitetssykehus, Rikshospitalet.

Forfatter har fylt ut ICMJE-skjemaet og oppgir ingen interessekonflikter.

\section{Mari Skylstad Kvernebo (f. 1977)}

er lege under spesialisering ved Seksjon for hudsykdommer, Oslo universitetssykehus, Rikshospitalet.

Forfatter har fylt ut ICMJE-skjemaet og oppgir ingen interessekonflikter.

\section{Nils-Jørgen Mørk (f. 1950)}

er spesialist i hud-og veneriske sykdommer, og overlege ved Seksjon for hudsykdommer, Oslo universitetssykehus, Rikshospitalet.

Forfatter har fylt ut ICMJE-skjemaet og oppgir ingen interessekonflikter.

\section{Petter Gjersvik (f. 1952)}

er spesialist i hud- og veneriske sykdommer, dr.med. og førsteamanuensis ved Institutt for klinisk medisin, Universitetet i Oslo.

Forfatter har fylt ut ICMJE-skjemaet og oppgir ingen interessekonflikter.

\section{Litteratur}

1. Moschella SL, Davis MDP. Neutrophilic dermatosis. I: Bolognia JL, Jorizzo JL, Rapini RP et al, red. Dermatology. 2. utg. Edinburgh: Mosby Elsevier, 2008: 379-402

2. French LE, Prins C. Erythema multiforme, Stevens-Johnson syndrome and toxic epidermal necrolysis. I: Bolognia JL, Jorizzo JL, Rapini RP et al, red. Dermatology. 2. utg. Edinburgh: Mosby Elsevier, 2008: 287-300

3. Ayangco L, Rogers RS 3rd. Oral manifestations of erythema multiforme. Dermatol Clin 2003; 21 : $195-205$

4. Lamoreux MR, Sternbach MR, Hsu WT. Erythema multiforme. Am Fam Physician 2006; 74: 1883-8.

5. Volcheck GW. Clinical evaluation and management of drug hypersensitivity. Immunol Allergy Clin North Am 2004: 24: 357-71, v.

6. Margolis RJ, Tonnesen MG, Harrist TJ et al. Lymphocyte subsets and Langerhans cells/indeterminate cells in erythema multiforme. J Invest Dermatol 1983: 81: 403-6.

7. Zohdi-Mofid M, Horn TD. Acrosyringeal concentration of necrotic keratinocytes in erythema multiforme: a clue to drug etiology. Clinicopathologic review of 29 cases. J Cutan Pathol 1997; 24 : 235-40.

8. Finan MC, Schroeter AL. Cutaneous immunofluorescence study of erythema multiforme: correlation with light microscopic patterns and etiologic agents. J Am Acad Dermatol 1984: 10: 497-506.

9. Borroni G, Biagi F, Ciocca OC et al. IgA anti-epidermal transglutaminase autoantibodies: a sensible and sensitive marker for diagnosis of dermatitis herpetiformis in adult patients. J Eur Acad Dermatol Venereol 2012. E-publisert 2.6.2012.

10. Avgerinou G, Papafragkaki DK, Nasiopoulou A et al. Correlation of antibodies against desmogleins 1 and 3 with indirect immunofluorescence and disease status in a Greek population with pemphigus vulgaris. J Eur Acad Dermatol Venereol 2012. E-publisert 5.1.2012.

11. Wojnarowska F, Kirtschig G, Highet AS et al. Guidelines for the management of bullous pemphigoid. Br J Dermatol 2002: 147: 214-21.

12. Lindbæk M. red. Nasjonale faglige retningslinjer for antibiotikabruk i primærhelsetjenesten. Oslo: Helsedirektoratet, 2008

13. Zylak CM, Standen JR, Barnes GR et al. Pneumomediastinum revisited. Radiographics 2000; 20: 1043-57.

14. Huff JC, Weston WL, Tonnesen MG. Erythema multiforme: a critical review of characteristics, diagnostic criteria, and causes. J Am Acad Dermatol 1983; 8: 763-75.

Mottatt 24.8. 2012, første revisjon innsendt 19.11. 2012, godkjent 18.1. 2013. Medisinsk redaktør Are Brean. 